\title{
Seasonality of rDNA- and rRNA-derived archaeal communities and methanogenic potential in a boreal mire
}

\author{
Heli Juottonen ${ }^{1}$, Eeva-Stiina Tuittila ${ }^{2}$, Sari Juutinen ${ }^{2}$, Hannu Fritze ${ }^{3}$ and Kim Yrjälä ${ }^{1}$ \\ ${ }^{1}$ Department of Biological and Environmental Sciences, General Microbiology, University of Helsinki, \\ Helsinki, Finland; ${ }^{2}$ Department of Forest Ecology, University of Helsinki, Helsinki, Finland and ${ }^{3}$ Vantaa \\ Research Unit, Finnish Forest Research Institute, Vantaa, Finland
}

\begin{abstract}
Methane $\left(\mathrm{CH}_{4}\right)$ emissions from boreal wetlands show considerable seasonal variation, including small winter emissions. We addressed the seasonality of $\mathrm{CH}_{4}$-producing microbes by comparing archaeal communities and the rates and temperature response of $\mathrm{CH}_{4}$ production in a boreal fen at three key phases of growing season and in winter. Archaeal community analysis by terminal restriction fragment length polymorphism and cloning of $16 \mathrm{~S}$ ribosomal DNA and reversetranscribed RNA revealed slight community shifts with season. The main archaeal groups remained the same throughout the year and were Methanosarcinaceae, Rice cluster II and Methanomicrobiales-associated Fen cluster. These methanogens and the crenarchaeal groups 1.1c and 1.3 were detected from DNA and RNA, but the family Methanosaetaceae was detected only from RNA. Differences between DNA- and RNA-based results suggested higher stability of DNA-derived communities and better representation of the active $\mathrm{CH}_{4}$ producers in RNA. Methane production potential, measured as formation of $\mathrm{CH}_{4}$ in anoxic laboratory incubations, showed prominent seasonality. The potential was strikingly highest in winter, possibly due to accumulation of methanogenic substrates, and maximal $\mathrm{CH}_{4}$ production was observed at ca. $30^{\circ} \mathrm{C}$. Archaeal community size, determined by quantitative PCR, remained similar from winter to summer. Low production potential in late summer after a water level draw-down suggested diminished activity due to oxygen exposure. Our results indicated that archaeal community composition and size in the boreal fen varied only slightly despite the large fluctuations of methanogenic potential. Detection of mRNA of the methanogenic mcrA gene confirmed activity of methanogens in winter, accounting for previously reported winter $\mathrm{CH}_{4}$ emissions.
\end{abstract}

The ISME Journal (2008) 2, 1157-1168; doi:10.1038/ismej.2008.66; published online 24 July 2008

Subject Category: microbial ecology and functional diversity of natural habitats

Keywords: Archaea; methane; peat; RNA; T-RFLP; winter

\section{Introduction}

In boreal regions, cold and wet conditions have promoted the development of peat-forming wetlands (mires) storing large amounts of carbon (Turunen et al., 2002). Together with other wetlands, boreal mires are among the most important natural sources of atmospheric methane $\left(\mathrm{CH}_{4}\right)$, a powerful greenhouse gas (Denman et al., 2007). Having short growing seasons and long snow-covered winters, the mires undergo strong seasonal changes. In contrast to temperate and tropical wetlands with less severe annual temperature shifts, $\mathrm{CH}_{4}$ emissions from

Correspondence: H Juottonen, Department of Biological and Environmental Sciences, General Microbiology, University of Helsinki, PO Box 56 (Viikinkaari 9), 00014 University of Helsinki, Finland.

E-mail: heli.juottonen@helsinki.fi

Received 28 January 2008; revised 4 June 2008; accepted 5 June 2008; published online 24 July 2008 northern wetlands show pronounced temperaturedriven seasonality (Whalen, 2005).

Methane is produced as a terminal step of anaerobic decomposition in water-saturated peat by a group of anaerobic Archaea, the methanogens. Temperature is one of the main factors controlling $\mathrm{CH}_{4}$ production in mires, together with substrate availability, water level and peat $\mathrm{pH}$ (Svensson and Sundh, 1992; Valentine et al., 1994; Bergman et al., 1998). Temperature influences microbial activity, but it may also alter the course of anaerobic decomposition, thus affecting the methanogenic pathway and substrate availability (Schulz et al., 1997). Seasonal temperature variation could therefore influence mire archaeal community either through direct temperature adaptation or indirectly through temperature-induced changes in substrate supply. Reported shifts in proportion of $\mathrm{H}_{2} / \mathrm{CO}_{2}$ dependent (hydrogenotrophic) and acetate-dependent (acetoclastic) $\mathrm{CH}_{4}$ production with incubation 
temperature have been accompanied by changes of archaeal communities in rice field soil (Chin et al., 1999; Fey and Conrad, 2000) but not in lake sediments and peat (Glissman et al., 2004; Metje and Frenzel, 2005, 2007). A recent study, in which arctic peat was incubated for several weeks, reported that some methanogen populations responded to temperature, whereas others were unaffected (Høj et al., 2008). The study also described dominance of non-methanogenic archaea at incubation temperatures below $10^{\circ} \mathrm{C}$ but increased contribution of methanogens above $10^{\circ} \mathrm{C}$.

Methane production potential in mires varies temporally (Yavitt et al., 1987; Duddleston et al., 2002), similarly to $\mathrm{CH}_{4}$ emissions. The pattern of variation, however, depends on vegetation and surface topography (Saarnio et al., 1997; Kettunen et al., 1999; Bergman et al., 2000). In mires where acetate was an important methanogenic precursor, the contributions of hydrogenotrophic and acetoclastic $\mathrm{CH}_{4}$ production have been observed to shift with season (Avery et al., 1999; Chasar et al., 2000). Methanogen community variation between mires has been related to vegetation, $\mathrm{pH}$ and hydrology (Galand et al., 2003; Juottonen et al., 2005; CadilloQuiroz et al., 2006; Rooney-Varga et al., 2007), but seasonality of wetland archaeal communities has scarcely been explored (Høj et al., 2005, 2006).

Although northern mires emit most $\mathrm{CH}_{4}$ during the warmest months, emissions in winter can contribute $4-33 \%$ of the annual $\mathrm{CH}_{4}$ flux (Dise, 1992; Alm et al., 1999). Because of their longer winters, boreal wetlands presumably have greater winter emissions than temperate wetlands (Melloh and Crill, 1996; Alm et al., 1999). Whether the emissions result from release of $\mathrm{CH}_{4}$ produced during warmer seasons or from continual methanogenic activity in cold remains unclear (Panikov and Dedysh, 2000).

Our first objective was to follow the methanogenic archaeal community composition in a boreal fen through seasonal temperature shifts. The communities were assessed by RNA/DNA extraction and terminal restriction fragment length polymorphism (T-RFLP) analysis of archaeal 16S rRNA genes, thus including also other groups of Euryarchaeota and Crenarchaeota. The study site, Siikaneva fen in southern Finland, is a focus of carbon cycling research, and its $\mathrm{CH}_{4}$ emissions have been continuously monitored throughout the year (Rinne et al., 2007; Riutta et al., 2007). Recent results showed that $20 \%$ of the annual carbon $\left(\mathrm{CO}_{2}\right)$ uptake was emitted as $\mathrm{CH}_{4}$, and winter emissions accounted for $5-8 \%$ of the flux (Rinne et al., 2007). Our second aim was to compare the rates and temperature response of $\mathrm{CH}_{4}$ production between seasons, with particular interest on winter potential. The third aim was to determine whether methanogenic archaea are active during winter.

\section{Materials and methods}

Site description and sample collection

The study site, Siikaneva, is a boreal fen in southern Finland $\left(61^{\circ} 50^{\prime} \mathrm{N}, 24^{\circ} 12^{\prime} \mathrm{E}\right)$. The site is nutrient poor (oligotrophic) and acidic with peat $\mathrm{pH}$ of 3.9-4.3. Vegetation in the sampled hollow and lawn areas consists of Scheuchzeria palustris, Carex rostrata, C. limosa, Andromeda polifolia, Vaccinium oxycoccus and Betula nana in the field layer, and Sphagnum majus, S. papillosum and $S$. balticum in the moss layer (Riutta et al., 2007). Samples were collected on 26 October 2005 (end of growing season before snow fall), 8 February 2006 (mid-winter), 23 May 2006 (after snowmelt) and 14 August 2006 (late summer). Table 1 shows average peat temperatures for the week preceding sampling and water levels at sampling dates. During the year studied, the minimum peat temperature at the depth of $20 \mathrm{~cm}$ was $-0.7^{\circ} \mathrm{C}$ in April and the maximum was $14.6^{\circ} \mathrm{C}$ in July (Rinne et al., 2007, unpublished data). Surface peat was frozen from early December to late April, but temperature at $20 \mathrm{~cm}$ remained between 0 and $0.7^{\circ} \mathrm{C}$ until mid-April and only went below $0{ }^{\circ} \mathrm{C}$ in late April. In February, peat was frozen to a depth of $8-15 \mathrm{~cm}$, and snow cover was $35 \mathrm{~cm}$.

At each sampling, a peat profile from three marked locations (overall $n=3$ ) several meters apart was collected with a box sampler $(8 \mathrm{~cm} \times 8 \mathrm{~cm} \times$ $90 \mathrm{~cm}$ ). The samples were transported to laboratory for immediate processing, with storage at $5{ }^{\circ} \mathrm{C}$ for no more than a few hours. Slices of $4 \mathrm{~cm}$ from each profile were taken for nucleic acid and $\mathrm{CH}_{4}$ analysis

Table 1 Environmental conditions, potential $\mathrm{CH}_{4}$ production and quantification of archaea

\begin{tabular}{|c|c|c|c|c|c|}
\hline \multirow[t]{2}{*}{ Sampling } & \multirow{2}{*}{$\begin{array}{l}\text { Peat temperature } \\
\text { at } 20 \mathrm{~cm}\left({ }^{\circ} \mathrm{C}\right)\end{array}$} & \multirow[t]{2}{*}{ Water level $(\mathrm{cm})$} & \multicolumn{2}{|c|}{ 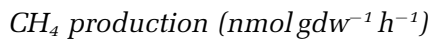 } & \multirow{2}{*}{$\begin{array}{c}\text { Archaeal } 16 S \text { rRNA } \\
\text { genes }\left(10^{9} \text { copies gdw } w^{-1}\right)\end{array}$} \\
\hline & & & $6^{\circ} \mathrm{C}$ & $14^{\circ} \mathrm{C}$ & \\
\hline October 2005 & 4.5 & $4 \pm 4$ & $0.4 \pm 0.6$ & $0.4 \pm 0.4$ & $0.8 \pm 1.0$ \\
\hline February 2006 & 0.1 & Frozen & $2.2 \pm 2.7$ & $11.9 \pm 6.1$ & $3.8 \pm 1.6$ \\
\hline May 2006 & 8.1 & $-4 \pm 3$ & $0.1 \pm 0.0$ & $7.4 \pm 4.5$ & $3.4 \pm 1.2$ \\
\hline August 2006 & 13.5 & $-23 \pm 4$ & $0.1 \pm 0.1$ & $1.5 \pm 0.6$ & $4.2 \pm 0.3$ \\
\hline
\end{tabular}

Abbrevation: gdw, grams dry weight.

Mean \pm s.d., $n=3$. Water level is negative below peat surface. 
at $20( \pm 2) \mathrm{cm}$ below the peat surface. This layer is generally water-submerged and showed higher $\mathrm{CH}_{4}$ production than the depths of 10 and $50 \mathrm{~cm}$ (unpublished data). Subsamples for nucleic acid analysis were frozen within few hours from sampling and kept frozen until extraction.

\section{Nucleic acid extraction \\ Total DNA and RNA were extracted from $0.4 \mathrm{~g}$ of frozen peat as in Korkama-Rajala et al. (2007). Briefly, peat was homogenized in a FastPrep cell disrupter (Qbiogene, Illkirch, France) at a speed setting $4.5 \mathrm{~m} \mathrm{~s}^{-1}$ for $30 \mathrm{~s}$ (adjusted from the original protocol). Phenol-chloroform-extracted nucleic acids were purified in a polyvinylpolypyrrolidone column and by polyethylene glycol precipitation, dissolved in TE buffer, and stored at $-70{ }^{\circ} \mathrm{C}$.}

\section{Reverse transcription}

RNA was prepared by treating $4 \mu \mathrm{l}$ of nucleic acid extracts with RQ1 DNase (Promega, Madison, WI, USA). To denature RNA secondary structure, $2 \mu \mathrm{l}$ of RNA and $200 \mathrm{ng}$ of random hexamer primers (Roche, Mannheim, Germany) in $9 \mu$ l of diethylpyrocarbonate-treated $\mathrm{H}_{2} \mathrm{O}$ were heated at $70^{\circ} \mathrm{C}$ for 5 min and chilled on ice. Reverse transcriptase buffer $(1 \times$, supplied with the enzyme) and $2 \mu \mathrm{l}$ of $10 \mathrm{mM}$ dNTPs were added before incubation at $25^{\circ} \mathrm{C}$ for $5 \mathrm{~min}$. After addition of RevertAid M-MuLV reverse transcriptase (200 U; Fermentas, Vilnius, Lithuania), reverse transcription (RT) was performed at $25^{\circ} \mathrm{C}$ for $10 \mathrm{~min}$ and $42^{\circ} \mathrm{C}$ for $60 \mathrm{~min}$, followed by inactivation at $70{ }^{\circ} \mathrm{C}$ for $10 \mathrm{~min}$. Total volume was $20 \mu \mathrm{l}$. To check for DNA contamination, DNasetreated extracts and control RT reactions without reverse transcriptase were used as PCR template.

\section{PCR}

Archaeal 16S rRNA gene fragments (ca. $800 \mathrm{bp}$ ) were amplified using primers Ar109f and Ar912rt (Grosskopf et al., 1998a; Lueders and Friedrich, 2002). Reactions $(50 \mu \mathrm{l})$ contained $1 \times$ DNA polymerase buffer, $0.2 \mathrm{mM}$ dNTPs, $15 \mathrm{pmol}$ of primers, $1 \mathrm{U}$ of DNA polymerase (Biotools, Madrid, Spain) and $1 \mu \mathrm{l}$ of total DNA (1:10 dilution) or RT products (1:5 dilution) as template. In PCR for T-RFLP, the reverse primer Ar912rt was 5'-labelled with 6-carboxyfuorescein (FAM), and the amount of primers was 10 pmol. Reaction conditions in a GeneAmp 2700 thermal cycler (Applied Biosystems, Foster City, CA, USA) were an initial denaturation $\left(94^{\circ} \mathrm{C}, 3 \mathrm{~min}\right), 28$ (DNA) or 32 (RT products) cycles of $94{ }^{\circ} \mathrm{C}$ for $45 \mathrm{~s}$, $52{ }^{\circ} \mathrm{C}$ for $1 \mathrm{~min}$ and $72{ }^{\circ} \mathrm{C}$ for $1.5 \mathrm{~min}$; and a final extension $\left(72^{\circ} \mathrm{C}, 7 \mathrm{~min}\right)$. Products were checked in $1 \%$ agarose gels with ethidium bromide staining. Fen cluster (FC) methanogens were detected with primers A-gE372 and A-gE540aR, which target a subgroup of the order Methanomicrobiales (CadilloQuiroz et al., 2006), in $25-\mu \mathrm{l}$ reactions with $10 \mathrm{pmol}$ of primers and the following reaction conditions: $94{ }^{\circ} \mathrm{C}$ for $1.5 \mathrm{~min}, 35$ cycles of $94^{\circ} \mathrm{C}$ for $45 \mathrm{~s}, 54^{\circ} \mathrm{C}$ for $1 \mathrm{~min}$ and $72{ }^{\circ} \mathrm{C}$ for $45 \mathrm{~s}$; and a final extension $\left(72^{\circ} \mathrm{C}\right.$, 5 min). Primer specificity was tested using FC and Rice cluster II (RCII) clones as template. mcrA mRNA was detected with primers of Luton et al. (2002) in $25-\mu$ l reactions, with 10 pmol of primers, and RT products (undiluted or 1:5 dilution) of winter samples as template. Reaction conditions were as in 16S rRNA gene PCR but with 35 cycles and 1-min extensions.

\section{T-RFLP analysis}

Archaeal PCR products were quantified with Qubit fluorometer (Invitrogen, Eugene, OR, USA) and by visual inspection of agarose gels. Product DNA (5-15 ng) was digested with restriction endonuclease TaqI (3 U; Fermentas) at $65^{\circ} \mathrm{C}$ for $4 \mathrm{~h}$ in a total volume of $20 \mu \mathrm{l}$. Digested DNA was ethanol precipitated and dissolved in a mixture of $15 \mu \mathrm{l}$ of Hi-Di formamide (Applied Biosystems) and $0.4 \mu \mathrm{l}$ of GeneScan-500 TAMRA size standard (Applied Biosystems). Fragments were separated by capillary electrophoresis in an ABI PRISM 310 Genetic Analyzer (Applied Biosystems). Each sample was electrophoresed twice. Fragments from 50 to $500 \mathrm{bp}$ in the electropherograms were analyzed with GeneScan software (v. 3.7; Applied Biosystems) using a minimum peak height threshold of 100 relative fluorescence units. To eliminate variation in DNA amount between samples, we estimated the total amount of each profile by summing peak areas. The lowest total area among the profiles divided by the total area of a given profile served as a correction factor for its peak heights (Dunbar et al., 2001). Peaks with corrected heights below 100 fluorescence units were excluded. Terminal restriction fragments (T-RFs) were assigned to phylogenetic groups by comparing in silico terminal fragments of clone sequences and by T-RFLP analysis of clones. Relative peak areas were used in data presentation and analysis.

\section{Community data analysis}

DNA- and RNA-derived T-RFLP data were compared by analysis of similarity using Bray-Curtis distances with PAST software v. 1.73 (O Hammer, DAT Harper, http://folk.uio.no/ohammer/past/). Analysis of similarity returns $R$-values; value of 0 indicates as large variation within the groups being compared as between them, and value of 1 indicates that variation between groups is always higher.

Detrended canonical correspondence analysis of T-RFLP data where detrending was done by segments revealed a short main gradient; length of the first axis was $<2$ s.d. units for DNA and RNA separately. Following this, we selected linear methods for further analysis (ter Braak and Prentice, 1988). We applied principal component analysis 
(PCA) to explore compositional variation in T-RFLP data. To determine factors that best explained variation in rDNA and rRNA communities, we used partial redundancy analysis (RDA) where spatial variation was levelled using the three sampling locations as categorical covariables. The factors tested were $\mathrm{CH}_{4}$ production potential (continuous variable) and the four different sampling times (categorical variables) together forming a variable season. Significance of the factors was tested using Monte Carlo permutations (499 permutations). All the analyses were carried out with Canoco for Windows 4.52 (ter Braak and Šmilauer, 2002). Level of significance in all statistical analyses was $P \leqslant 0.05$. The effect of variables with higher risk level is mentioned when considered close enough to 0.05 to be relevant.

\section{Cloning and DNA sequencing}

Five clone libraries were constructed from selected rDNA- and rRNA-derived archaeal PCR products representing all four samplings. After gel purification with Wizard SV Gel and PCR Clean-Up kit (Promega), PCR products were ligated into pGEM-T Easy vector (Promega) and transformed into Escherichia coli $\mathrm{DH} 5 \alpha$ competent cells. Inserts from ca. 30 blue-white-screened clones from each library were amplified with primers Ar109f and Ar912rt and digested with TaqI at $65^{\circ} \mathrm{C}$ for RFLP screening. Fragments were separated by agarose gel electrophoresis in 3\% Synergel (Diversified Biotech, Boston, MA, USA). On the basis of RFLP banding patterns, clones were divided into restriction groups. Coverage of clone libraries was calculated as in Galand et al. (2003).

Two to four representatives of each RFLP group were amplified with vector-specific RP (5'-TTTCAC ACAGGAAACAGCTATGAC- $3^{\prime}$ ) and UP (5'-CGACGT TGTAAAACGACGGCCAGT-3') primers and sequenced with vector primer T7 or SP6. The sequences have been submitted to the EMBL database under accession nos. AM905390-AM905421.

\section{Phylogenetic analysis}

Partial 16S rRNA gene sequences (ca. $800 \mathrm{bp}$ ) were compared to database sequences by BLAST searches (http://ncbi.nlm.nih.gov/BLAST). The presence of chimeric sequences was checked with the Bellerophon server (http://foo.maths.uq.edu.au/ huber/ bellerophon.pl) (Huber et al., 2004). Sequences were aligned with NAST alignment tool on the Greengenes server (http://greengenes.lbl.gov) (DeSantis et al., 2006). The alignment was edited manually to remove ambiguous positions. A maximum likelihood tree was constructed with PhyML (http:// atgc.lirmm.fr/phyml/) (Guindon and Gascuel, 2003) using a general time reversible nucleotide substitution model with estimated proportion of invariable sites and gamma distribution parameter. The model was selected with the FindModel server (http:// hcv.lanl.gov/content/hcv-db/findmodel/findmodel. $\mathrm{html}$ ). Bootstrap values were generated from 100 samplings in PhyML.

Measurement of potential methane production

Rates of potential $\mathrm{CH}_{4}$ production were determined without substrate addition in short-term incubations. Within few hours from sampling, $15 \mathrm{ml}$ of peat was transferred to $120-\mathrm{ml}$ infusion bottles containing $30 \mathrm{ml}$ of $\mathrm{N}_{2}$-flushed distilled $\mathrm{H}_{2} \mathrm{O}$. Five bottles were prepared from each peat slice (one for each incubation temperature). The bottles were flushed with $\mathrm{N}_{2}$ and closed with butyl rubber stoppers. After 4-6 days at $5{ }^{\circ} \mathrm{C}, \mathrm{N}_{2}$ flushing was repeated twice to remove residual $\mathrm{CH}_{4}$ before the start of the temperature experiments. The bottles were incubated at 5.7 ( \pm 0.7$), 14.2$ ( \pm 0.9$), 24.2( \pm 0.3), 32.8( \pm 1.9$ ) or 40.2 $( \pm 3.3)^{\circ} \mathrm{C}$ (mean \pm s.d. for the four experiments) in water baths inside incubators in dark for 90-95 h. In October, incubation time was $70 \mathrm{~h}$ and no samples were incubated at the highest temperature. Methane concentration was determined daily by gas chromatography as in Jaatinen et al. (2005). Rates of potential $\mathrm{CH}_{4}$ production were calculated for the period of linear or closest to linear increase in $\mathrm{CH}_{4}$ concentration after the 1-day lag phase that some samples exhibited.

\section{Real-time quantitative PCR}

Archaeal 16S rRNA genes were quantified by real-time quantitative PCR with primers Arch967F (5'-AATTGGCGGGGGAGCAC- ${ }^{\prime}$ ) and Arch1060R (5'-GGCCATGCACCWCCTCTC-3') (Cadillo-Quiroz et al., 2006 and references therein). Reactions $(20 \mu \mathrm{l})$ contained LightCycler 480 SYBR Green I Master reaction mixture (Roche), $6 \mathrm{pmol}$ of primers and $1 \mu \mathrm{l}$ of total DNA (dilutions 1:10 and 1:20). Reactions were carried out in triplicate. Reaction conditions in a LightCycler 480 instrument (Roche) were denaturation at $95{ }^{\circ} \mathrm{C}$ for $5 \mathrm{~min}$ and 45 cycles of $95{ }^{\circ} \mathrm{C}$ for $10 \mathrm{~s}, 60^{\circ} \mathrm{C}$ for $15 \mathrm{~s}$ and $72{ }^{\circ} \mathrm{C}$ for $10 \mathrm{~s}$. Data were collected during the extension step. For creating a standard curve, 16S rRNA genes were amplified from total DNA with methanogen primers 146f and 1324r (Marchesi et al., 2001; Galand et al., 2003). The amplicons were gel purified as above, quantified with Qubit fluorometer, and diluted to contain $10^{1}-10^{8}$ copies of the amplicon. The standard curve was created from duplicate reactions of each standard. Inspection of melting curves and analysis in 3\% agarose gel ensured specificity of standard and sample products. Results are expressed per gram dry weight of peat (density of peat $\sim 0.1 \mathrm{~g}$ (dry weight) $\mathrm{cm}^{-3}$ ).

\section{Results}

T-RFLP fingerprinting of archaeal communities Archaeal T-RFLP profiles from four seasons displayed altogether 11 T-RFs, with individual profiles 


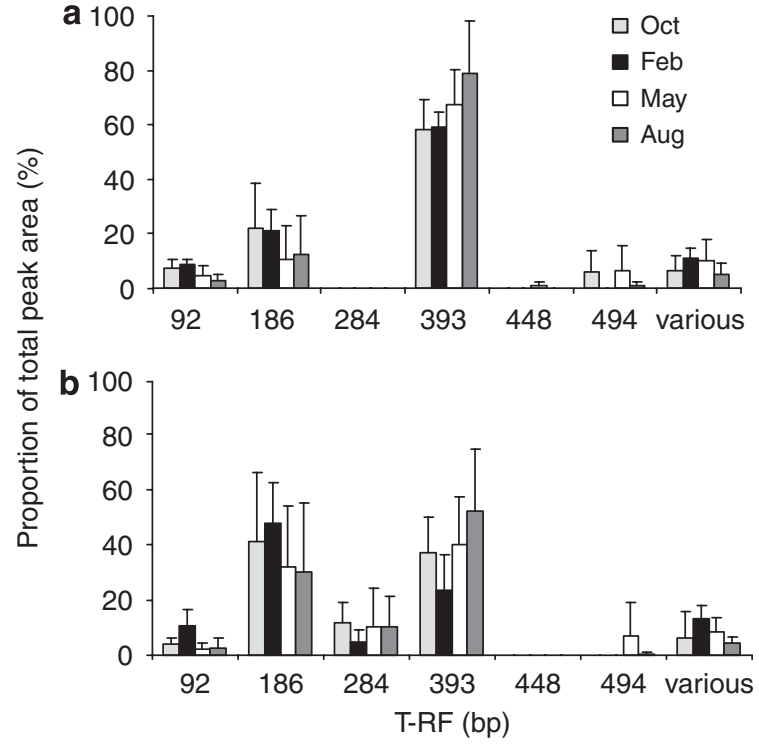

Figure 1 Terminal restriction fragment (T-RF) sizes and relative proportions in archaeal 16S rDNA- (a) and rRNA-derived (b) terminal restriction fragment length polymorphism (T-RFLP) profiles from the boreal fen at four times of the year. Bars represent mean + s.d. of relative peak areas in profiles from three peat cores per season. 'Various' includes unidentified minor T-RFs (62, 84, 115, 119 and $175 \mathrm{bp})$.

showing 4-7. DNA- and RNA-derived communities overlapped but also clearly differed (analysis of similarity $R=0.40, P<0.001)$. The most explicit difference was the occurrence of a 284-bp T-RF in rRNA profiles only (Figure 1). In rDNA-derived profiles the 393-bp T-RF predominated, but in rRNA profiles the dominant T-RF was either 393 or $186 \mathrm{bp}$ (Figure 1).

The 186- and 393-bp T-RFs were the most prominent ones all year round (Figure 1) and nearly ubiquitous; only in one August profile the $186 \mathrm{bp}$ peak was absent. The main peaks' relative proportions suggested shifts between winter and summer. The 186-bp peak had on average 13\% (range 2-36\%) larger proportion and the 393-bp peak $24 \%$ (range 5-37\%) smaller proportion in February than in August (Figure 1). These shifts occurred in both rDNA and rRNA profiles. Additionally, winter rRNA profiles showed a lower proportion of the 284-bp T-RF and higher proportion of the 92-bp T-RF. These community shifts and their significance were further investigated by PCA and RDA of T-RFLP data. The first PCA axis, which is related to the main compositional variation, separated rDNA-derived communities of February and October from May and August (Figure 2a). The main variation was associated with differences in the relative abundance of the 186- and 393-bp T-RFs. For rRNA data, the clearest separation of seasons was between February and August (Figure 2b). Although none of the explaining factors was statistically significant in strict terms for rDNA data, partial RDA revealed that temporal variation was the best predictor for compositional variation:
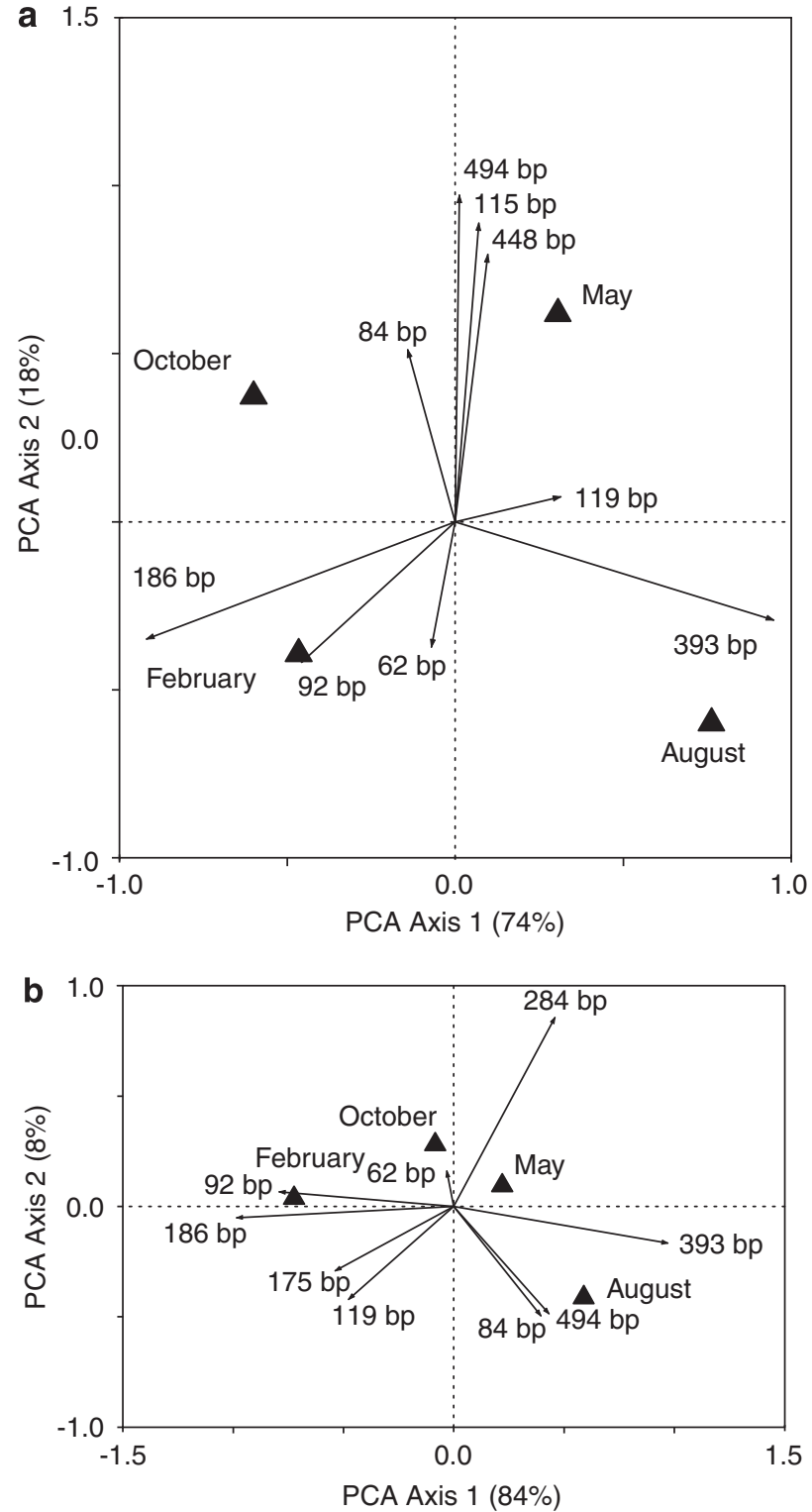

Figure 2 Principal component analysis (PCA) of archaeal rDNA(a) and rRNA-derived (b) T-RFLP community data from peat collected at four times of the year. The values in parenthesis indicate the percentage of community variation explained by the axes.

the sampling times explained $25 \%$ of DNA community variation $(P=0.088)$. For rRNA data, however, a better and stronger explanatory variable turned out to be $\mathrm{CH}_{4}$ production potential, which explained $38 \%$ of RNA community variation $(P=0.020)$.

Phylogenetic analysis and identification of T-RFS Construction of $16 \mathrm{~S}$ rDNA- and rRNA-derived clone libraries allowed identification of all major T-RFs (Table 2). Coverage values of the libraries ranged from $83 \%$ to $100 \%$. Library compositions were in good agreement with the corresponding T-RFLP profiles (data not shown). The libraries supported 
Table 2 Identification of T-RFs based on the phylogenetic distribution of RFLP-screened archaeal clones in rDNA- and rRNA-derived libraries

\begin{tabular}{llr}
\hline T-RF (bp) & Phylogenetic affiliation & No. of clones \\
\hline 92 & Methanobacteriaceae/LDS cluster & 6 \\
186 & Methanosarcinaceae & 42 \\
186 & Group 1.1c Crenarchaeota & 7 \\
284 & Methanosaetaceae & 7 \\
393 & Fen cluster (Methanomicrobiales) & 22 \\
393 & Rice cluster II & 36 \\
448 & Thermoplasmatales-related & 2 \\
494 & Rice cluster II & 4 \\
$>700$ & Group 1.3 Crenarchaeota & 9 \\
$>800$ & Group 1.3 Crenarchaeota/ARMAN & 7 \\
\hline
\end{tabular}

Abbrevations: RFLP, restriction fragment length polymorphism; T-RF, terminal restriction fragment.

${ }^{a}$ No differentiation of groups in RFLP.

the detection of the 284-bp T-RF exclusively from RNA. All three RNA-derived libraries contained clones with this T-RF, but the two DNA-derived libraries revealed none. Phylogenetic analysis assigned clone sequences with the 284-bp T-RF to Methanosaetaceae (Figure 3). Sequences with the 186-bp T-RF grouped with Methanosarcina lacustris and with Methanosarcinaceae sequences from peat, but also with group 1.1c Crenarchaeota (Figure 3). On the basis of RFLP patterns, Methanosarcinaceae clones were consistently more numerous in clone libraries (30 $\pm 16 \%$, mean \pm s.d. of five libraries) than $1.1 \mathrm{c}$ crenarchaea clones $(5 \pm 4 \%)$. In total, $86 \%$ of the clones with the 186-bp T-RF belonged to Methanosarcinaceae (Table 2), and therefore the T-RF most likely represented mainly this group. The other main T-RF of $393 \mathrm{bp}$ occurred in sequences of Methanomicrobiales-associated methanogenic FC (Galand et al., 2002; Bräuer et al., 2006) and the uncultured but putatively methanogenic RCII (Grosskopf et al., 1998b) (Figure 3). RFLP analysis differentiated FC and RCII in clone library data, but because different libraries revealed only FC, only RCII, or $40 \%$ FC and $60 \%$ RCII, it was not possible to estimate the relative contributions of these groups. To gain further insight into the identity of the 393-bp T-RF, the occurrence of FC was investigated with Methanomicrobiales-specific 16S rRNA gene primers, which amplify FC (Cadillo-Quiroz et al., 2006) but, according to sequence analysis and PCR of Siikaneva clones, do not amplify RCII. Both total DNA and reverse-transcribed RNA from 11 out of 12 samples yielded good PCR products (data not shown), indicating the presence of FC throughout the year.

Other sequenced clones, representing minor T-RFs, were affiliated with Methanobacteriaceae, with euryarchaea belonging to an uncultured Lake Dagow Sediment cluster (LDS, Glissman et al., 2004) or distantly related to Thermoplasmatales, and with group 1.3 Crenarchaeota (Table 2 and Figure 3). Two sequences (SnDF3 and SnDO5) showed the highest similarity $(90 \%)$ to an uncultured euryarchaeote
ARMAN-2 from acid mine drainage (Baker et al., 2006). Because group 1.3 and ARMAN-2-related T-RFs were outside the size range of the T-RFLP standard, they were not included in Figure 1. No chimeric sequences were detected. Five minor T-RFs (62, 84, 115, 119 and $175 \mathrm{bp})$ remained unidentified with no matching sequences.

Seasonality and temperature response of potential $\mathrm{CH}_{4}$ production

In parallel with the RNA/DNA analyses, we determined the endogenous methanogenic potential of the peat samples at field temperatures (Table 1). The potential was also measured at higher temperatures to determine the temperature of maximal production (Figure 4). Rates at 6 and $14{ }^{\circ} \mathrm{C}$ were small, varying from 0 to $18.7 \mathrm{nmol} \mathrm{g}^{-1} \mathrm{~h}^{-1}$ (Table 1). The potential at $14^{\circ} \mathrm{C}$ varied significantly with season $(P=0.024$, Kruskal-Wallis test). Production potential increased from October to February, and the highest $\mathrm{CH}_{4}$ production was unexpectedly observed in winter (Table 1). The potential remained fairly high in the following spring but decreased clearly by August.

Methane production rates were markedly higher above $14{ }^{\circ} \mathrm{C}$, with maximal potential between 27 and $33^{\circ} \mathrm{C}$ (Figure 4). In May and August, however, the rates of two samples out of three showed no clear difference between 24 and $33^{\circ} \mathrm{C}$ (Figure 4). Seasonal production rates differed at $33^{\circ} \mathrm{C}(P=0.030$, oneway analysis of variance). The high production potential in winter was even more striking at $33^{\circ} \mathrm{C}$, with rates from 263 to $475 \mathrm{nmol} \mathrm{g}^{-1} \mathrm{~h}^{-1}$. Compared to the rates of the other seasons at $33^{\circ} \mathrm{C}$, ranging from 17 to $277 \mathrm{nmol} \mathrm{g}^{-1} \mathrm{~h}^{-1}$, the winter rates were on average 3.5 and up to 28 times as large.

\section{Quantification of archaea}

To elucidate factors behind the variation of $\mathrm{CH}_{4}$ production potential, we determined the size of the archaeal community by quantitative PCR of $16 \mathrm{~S}$ rDNA. Archaeal numbers differed with season $(P=0.025$, one-way analysis of variance), with October showing the lowest numbers (Table 1). In contrast to the differing $\mathrm{CH}_{4}$ production potentials of February and August, the archaeal community size in winter and summer was similar (Table 1).

\section{Detection of mcrA RNA in winter peat}

To confirm the presence of active methanogens in winter, we attempted to detect the mRNA of mcrA, a methanogen-specific marker gene coding for methylcoenzyme $\mathrm{M}$ reductase and indispensable for $\mathrm{CH}_{4}$ production (Friedrich, 2005). Amplification of mcrA cDNA was successful from all winter samples (Figure 5).

\section{Discussion}

Our results demonstrated strong seasonality of $\mathrm{CH}_{4}$ production in a boreal fen, with surprisingly high 


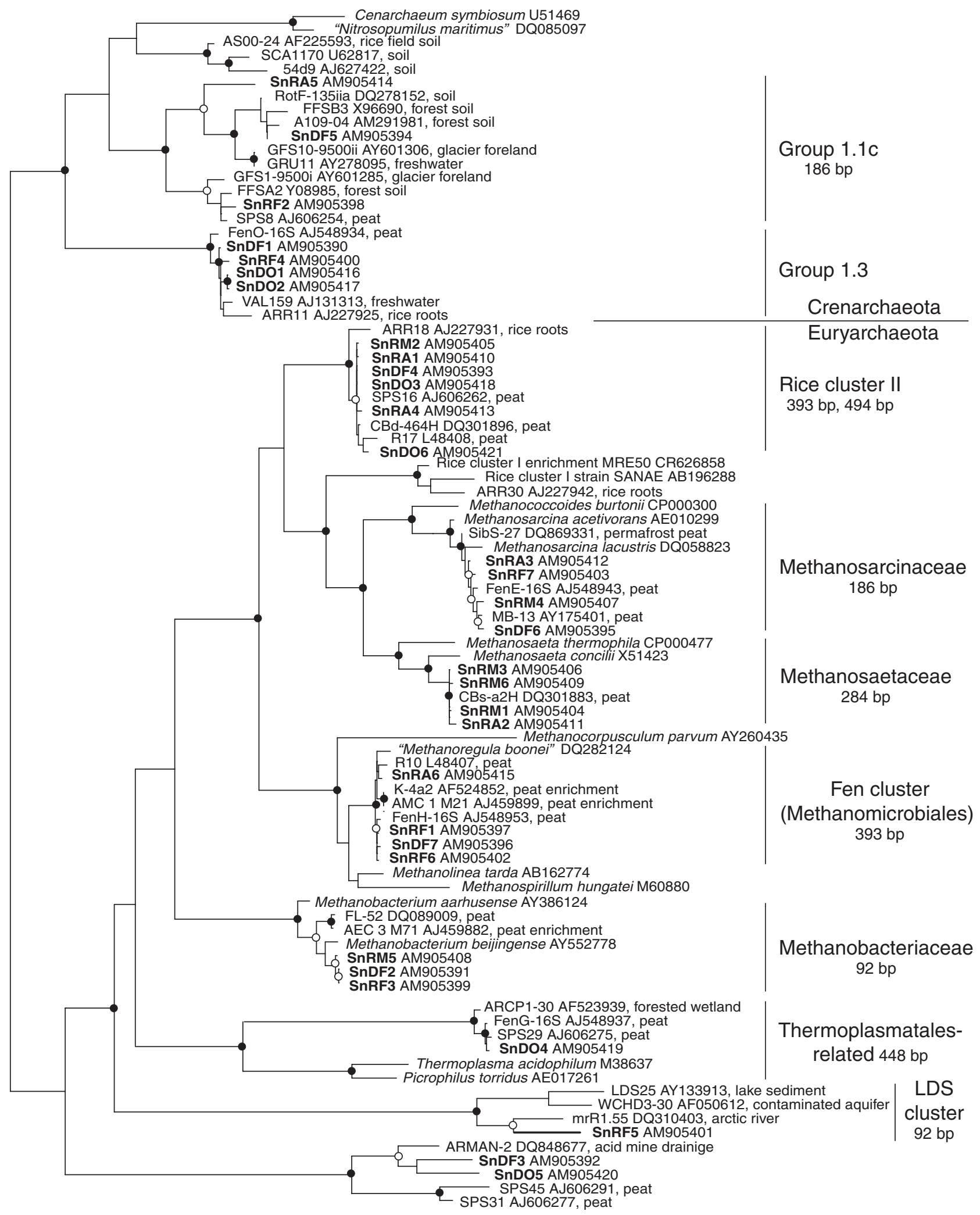

Figure 3 Maximum likelihood tree representing partial archaeal 16S rRNA gene sequences (ca. $650 \mathrm{bp}$ ) from the boreal fen (in bold) and reference sequences. Size of terminal restriction fragment is indicated for the groups detected by terminal restriction fragment length polymorphism (T-RFLP). Scale indicates $10 \%$ sequence divergence. Nodes with bootstrap values $>95 \%$ are indicated with filled circles and $>75 \%$ with unfilled circles. The tree was rooted between Crenarchaeota and Euryarchaeota. In bold sequence names, D denotes sequences from rDNA and R from reverse-transcribed rRNA. O, October; F, February; M, May and A, August stand for sampling dates. Group 1.1c Crenarchaeota also contains a sequence cluster known as 1.1c associated or group 1.1d (Kemnitz et al., 2007). 


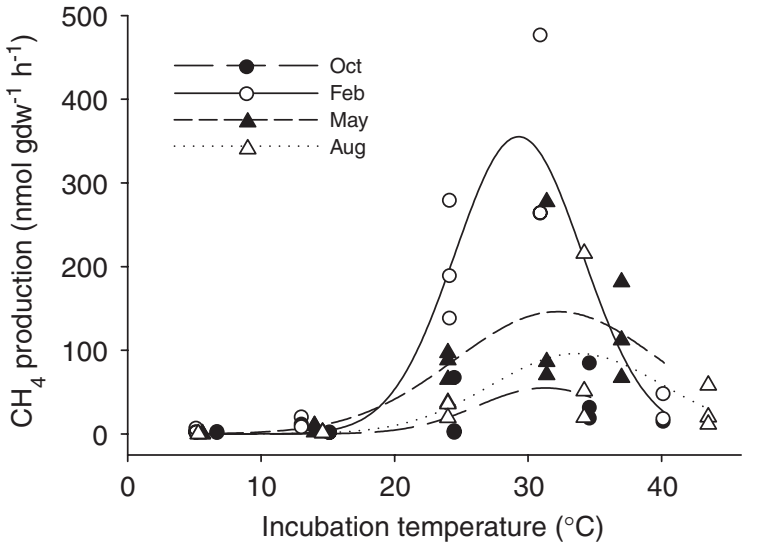

Figure 4 Temperature response of potential $\mathrm{CH}_{4}$ production at four times of the year. Peat samples $(n=3)$ were incubated without added substrates at temperatures from 5 to $43^{\circ} \mathrm{C}$ for 4 days. Lines are Gaussian fits for visual aid. gdw, grams dry weight.

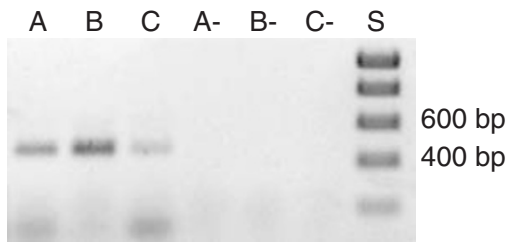

Figure 5 Amplification of the methanogenic mcrA gene fragment $(470 \mathrm{bp})$ from reverse-transcribed RNA extracted from winter peat of three replicate peat profiles (A, B and C). A-, Band $\mathrm{C}-$ are control reactions with DNase-treated nucleic acid extracts as PCR template. Size standard (S) on the right.

methanogenic potential in winter, and less conspicuous shifts in archaeal community structure. To the best of our knowledge, this is the first report of temporal comparison of archaeal communities together with methanogenic potential in a boreal wetland. Moreover, the detection of methanogenic mcrA mRNA revealed the presence of active methanogens in winter.

High $\mathrm{CH}_{4}$ production potential in winter peat has not been reported before. The very few reports on winter $\mathrm{CH}_{4}$ production have observed, in temperate wetlands, the lowest potentials in winter (Yavitt et al., 1987; Avery et al., 1999). Our opposite observation in boreal peat could be due to the lower autumn temperatures. In a boreal fen, potential $\mathrm{CH}_{4}$ production increased towards autumn (Saarnio et al., 1997; Kettunen et al., 1999). The authors suggested that when temperature and thus methanogenic activity dropped, substrates accumulated. High levels of substrates accumulating as a result of bacterial activity in autumn and winter would, together with sufficient methanogenic biomass, allow the high $\mathrm{CH}_{4}$ production potential in February.

We propose that methanogens in the unfrozen peat beneath the snow cover exhibit low activity. The high $\mathrm{CH}_{4}$ production potential and the archaeal community size comparable to spring and summer indicated that methanogenic biomass in winter was substantial. Analysis of rRNA revealed the same archaeal groups as in warmer seasons, and the detection of mcrA mRNA confirmed active methanogenesis. Methane production has been detected at $1{ }^{\circ} \mathrm{C}$ and even below (Simankova et al., 2003; Wagner et al., 2007); at our site peat temperature at the depth of $20 \mathrm{~cm}$ remained above $0{ }^{\circ} \mathrm{C}$ all winter except a few days before snowmelt. Furthermore, anaerobic conditions beneath the snow and ice cover are highly stable, which may be beneficial for methanogenesis in cold (Kotsyurbenko, 2005). The small winter $\mathrm{CH}_{4}$ emission and the $\mathrm{CH}_{4}$ pulse after snowmelt, which have been detected in this fen (Rinne et al., 2007; Riutta et al., 2007), could therefore result from active but severely temperature-limited methanogenesis during winter. The high temperature of maximal potential $\mathrm{CH}_{4}$ production and the stark contrast between production at 14 and $24{ }^{\circ} \mathrm{C}$ (Figure 4) showed that field temperatures limited methanogenesis not only in winter but also throughout the year.

The summer of 2006 was exceptionally dry, and the water level dropped below the sampled depth of $20 \mathrm{~cm}$. Consequently, inactivation of the anaerobic microbial community by exposure to oxygen may have resulted in the low methanogenic potential in late summer, despite undiminished archaeal numbers. Yet because of the higher field temperatures, the archaeal community in late summer during low methanogenic potential most likely produced more $\mathrm{CH}_{4}$ in situ than the community in winter when the potential was markedly higher.

Comparison of rDNA and rRNA data has commonly revealed overlapping microbial communities with DNA- and RNA-exclusive members (Duineveld et al., 2001; Mengoni et al., 2005; Gentile et al., 2006). Here, the similarity of rDNA- and rRNAderived phylogenetic groups demonstrated an expected level of agreement, whereas the observed community structures differed. Ribosomal RNA content is generally highest in actively growing cells although exceptions are known (Kerkhof and Ward, 1993; Kerkhof and Kemp, 1999). Owing to the lability of RNA, analysis of rRNA can nevertheless be considered to emphasize the metabolically active population and rDNA the numerically abundant. The prominence of Methanosarcinaceae (186 bp T-RF) in rRNA compared to rDNA (Figure 1) might indicate high cellular rRNA content and thus potentially higher methanogenic activity. The detection of Methanosaetaceae exclusively from RNA could signify the high rRNA content of a small population, which in DNA analysis was below the detection limit. Because members of Methanosaetaceae have slow growth rates (Jetten et al., 1992), their environmental responses may primarily appear in rRNA instead of rDNA, as has been observed in an anaerobic digester and rice field soil (Delbes et al., 2001; Lueders and Friedrich, 2002). The high variability of rRNA-derived communities (Figure 1b) 
implied small-scale spatial or temporal fluctuations in archaeal activity, predominating over the more stable patterns of rDNA-derived populations. Considering the rRNA community variation and its connection with $\mathrm{CH}_{4}$ production as indicated by the partial RDA, it is noteworthy that a recent study suggested $\mathrm{CH}_{4}$ fluxes to be controlled more by cellular activity of methanogens than by cell numbers (Röling, 2007).

In agreement with the methanogenic potential of the studied peat layer, methanogens dominated the archaeal communities. The main groups Methanosarcinaceae, FC and RCII have been prominent in northern wetlands, and many of the 16S rRNA gene sequences of these groups and of Methanosaetaceae and Methanobacteriaceae grouped with sequences from boreal, temperate and arctic peat (Basiliko et al., 2003; Galand et al., 2003; Horn et al., 2003; Kotsyurbenko et al., 2004; Høj et al., 2005; Metje and Frenzel, 2005, 2007; Cadillo-Quiroz et al., 2006). The results hint at the occurrence of both hydrogenotrophic (Methanomicrobiales-associated FC and Methanobacteriaceae) and acetoclastic (Methanosaetaceae) methanogenesis. Members of Methanosarcinaceae could be acetoclastic, hydrogenotrophic or methylotrophic, because many strains in this versatile family have all three pathways (Garcia et al., 2000). FC has been a dominant group in highly acidic mires (Juottonen et al., 2005; Cadillo-Quiroz et al., 2006), and its detection is in accordance with the low $\mathrm{pH}$ of this site. The FC sequences showed 97-98\% sequence similarity to 'Candidatus Methanoregula boonei', the first cultured FC member, which was isolated from an acidic temperate bog and has a $\mathrm{pH}$ optimum of ca. 5 , the lowest known for a methanogen (Bräuer et al., 2006).

Crenarchaea of groups $1.1 \mathrm{c}$ and 1.3 were less prevalent but present in peat at different seasons. Group 1.1c has been detected in other low $\mathrm{pH}$ soil environments such as forest soils (Jurgens et al., 1997; Kemnitz et al., 2007; Nicol et al., 2007). Group 1.3 (or Rice cluster IV) appears to be widespread in northern wetlands (Galand et al., 2003; Utsumi et al., 2003; Kotsyurbenko et al., 2004; Høj et al., 2006; Rooney-Varga et al., 2007). Function of these crenarchaeal groups remains unknown, but their detection in water-saturated peat suggests they might survive in anoxic conditions or thrive in oxic microenvironments, for example, in the vicinity of vascular plant roots (Simon et al., 2000).

It has been suggested that root exudate-utilizing microbes thrive in summer, but when plant activity ceases in winter, substrate use shifts towards recalcitrant dead plant material (Lipson et al., 2002). Bergman et al. (2000) reported that boreal mire sites with distinct plant communities showed different seasonal patterns of $\mathrm{CH}_{4}$ production and that a notable source of temporal variation was substrate supply. Here, substrate quality or quantity may have induced the seasonal differences in $\mathrm{CH}_{4}$ production potential and also the small fluctuation of archaeal communities between summer and winter. For instance, members of Methanosarcinaceae have been prominent at high substrate levels (Fey and Conrad, 2000; Lu et al., 2005), whereas hydrogenotrophic methanogenesis, the only known pathway for Methanomicrobiales and thus FC, has been associated with low substrate availability of peat (Hornibrook et al., 1997). Hydrogenotrophic Rice cluster I methanogens have also been associated with low $\mathrm{H}_{2}$ availability (Sakai et al., 2007). Whether the observed shifts of relative T-RF abundances represent substrate-dependent changes in size or activity of particular methanogen populations warrants further study. Considering the variable contribution of FC and RCII in clone libraries, the abundance of these poorly known groups would be particularly interesting to monitor in relation to peat chemistry and vegetation.

In conclusion, with their distinct seasons, boreal mires are excellent ecosystems for elucidating the microbial activity behind the annual cycles of wetland greenhouse gas emissions in the changing climate. Season affected particularly the methanogenic potential but also, to a lesser extent, the archaeal communities and quantities in the studied boreal fen. Assessing not only rDNA but also rRNA provided a more comprehensive description of community composition over the seasons. Analysis of rDNA revealed archaeal communities with relatively stable composition and small temporal variation, whereas the rRNA-derived communities appeared more dynamic. The detected methanogenic activity in winter calls attention to wetland microbial processes in cold. Further studies addressing the seasonal dynamics of both methanogens and the bacterial substrate producers in different types of mires have potential to advance understanding of community responses to peat chemistry and vegetation.

\section{Acknowledgements}

We thank Anuliina Putkinen, Marjo Nissinen and Robin Zimmermann for technical assistance, Krista Peltoniemi and Mirva Sandberg for advice on RNA extraction, Janne Levula, Jouni Meronen, Tero Tuomivirta and Paavo Ojanen for help with sampling, and Janne Rinne and Sami Haapanala for field temperature data. Financial support was received from the Academy of Finland (project 109816), Emil Aaltonen Foundation and Viikki Graduate School in Molecular Biosciences.

\section{References}

Alm J, Saarnio S, Nykänen H, Silvola J, Martikainen PJ. (1999). Winter $\mathrm{CO}_{2}, \mathrm{CH}_{4}$ and $\mathrm{N}_{2} \mathrm{O}$ fluxes on some natural and drained boreal peatlands. Biogeochemistry 44: 163-186.

Avery GB, Shannon RD, White JR, Martens CS, Alperin MJ. (1999). Effect of seasonal changes in the pathways of 
methanogenesis on the $\delta^{13} \mathrm{C}$ values of pore water methane in a Michigan peatland. Global Biogeochem Cycles 13: 475-484.

Baker BJ, Tyson GW, Webb RI, Flanagan J, Hugenholtz P, Allen EE et al. (2006). Lineages of acidophilic Archaea revealed by community genomic analysis. Science 314: 1933-1935.

Basiliko N, Yavitt JB, Dees PM, Merkel SM. (2003). Methane biogeochemistry and methanogen communities in two northern peatland ecosystems, New York State. Geomicrobiol J 20: 563-577.

Bergman I, Klarqvist M, Nilsson M. (2000). Seasonal variation in rates of methane production from peat of various botanical origins: effects of temperature and substrate quality. FEMS Microbiol Ecol 33: 181-189.

Bergman I, Svensson BH, Nilsson M. (1998). Regulation of methane production in a Swedish acid mire by $\mathrm{pH}$, temperature and substrate. Soil Biol Biochem 30: 729-741.

Bräuer SL, Cadillo-Quiroz H, Yashiro E, Yavitt JB, Zinder SH. (2006). Isolation of a novel acidiphilic methanogen from an acidic peat bog. Nature 442: 192-194.

Cadillo-Quiroz H, Bräuer SL, Yashiro E, Sun C, Yavitt JB, Zinder SH. (2006). Vertical profiles of methanogenesis and methanogens in two contrasting acidic peatlands in central New York State, USA. Environ Microbiol 8: 1428-1440.

Chasar LS, Chanton JP, Glaser PH, Siegel DI. (2000). Methane concentration and stable isotope distribution as evidence of rhizospheric processes: comparison of a fen and bog in the glacial Lake Agassiz peatland complex. Ann Bot 86: 655-663.

Chin KJ, Lukow T, Conrad R. (1999). Effect of temperature on structure and function of the methanogenic archaeal community in an anoxic rice field soil. Appl Environ Microbiol 65: 2341-2349.

Delbes C, Moletta R, Godon JJ. (2001). Bacterial and archaeal 16S rDNA and 16S rRNA dynamics during an acetate crisis in an anaerobic digestor ecosystem. FEMS Microbiol Ecol 35: 19-26.

Denman KL, Brasseur G, Chidthaisong A, Ciais P, Cox PM, Dickinson RE et al. (2007). Couplings between changes in the climate system and biogeochemistry. In: Solomon S, Qin D, Manning M, Chen Z, Marquis M, Averyt KB et al. (eds). Climate Change 2007: the Physical Science Basis. Contribution of Working Group I to the Fourth Assessment Report of the Intergovernmental Panel on Climate Change. Cambridge University Press: Cambridge, United Kingdom and New York, NY, USA.

DeSantis TZ, Hugenholtz P, Keller K, Brodie EL, Larsen N, Piceno YM et al. (2006). NAST: a multiple sequence alignment server for comparative analysis of $16 \mathrm{~S}$ rRNA genes. Nucleic Acids Res 34: W394-W399.

Dise NB. (1992). Winter fluxes of methane from Minnesota peatlands. Biogeochemistry 17: 71-83.

Duddleston KN, Kinney MA, Kiene RP, Hines ME. (2002). Anaerobic microbial biogeochemistry in a northern bog: acetate as a dominant metabolic end product. Global Biogeochem Cycles 16: 1063, doi:10.1029/ $2001 \mathrm{~GB} 001402$.

Duineveld BM, Kowalchuk GA, Keijzer A, van Elsas JD, van Veen JA. (2001). Analysis of bacterial communities in the rhizosphere of chrysanthemum via denaturing gradient gel electrophoresis of PCR-amplified 16S rRNA as well as DNA fragments coding for 16S rRNA. Appl Environ Microbiol 67: 172-178.
Dunbar J, Ticknor LO, Kuske CR. (2001). Phylogenetic specificity and reproducibility and new method for analysis of terminal restriction fragment profiles of 16S rRNA genes from bacterial communities. Appl Environ Microbiol 67: 190-197.

Fey A, Conrad R. (2000). Effect of temperature on carbon and electron flow and on the archaeal community in methanogenic rice field soil. Appl Environ Microbiol 66: $4790-4797$.

Friedrich MW. (2005). Methyl-coenzyme M reductase genes: unique functional markers for methanogenic and anaerobic methane-oxidizing Archaea. Methods Enzymol 397: 428-442.

Galand PE, Fritze H, Yrjälä K. (2003). Microsite-dependent changes in methanogenic populations in a boreal oligotrophic fen. Environ Microbiol 5: 1133-1143.

Galand PE, Saarnio S, Fritze H, Yrjälä K. (2002). Depth related diversity of methanogen Archaea in Finnish oligotrophic fen. FEMS Microbiol Ecol 42: 441-449.

Garcia JL, Patel BKC, Ollivier B. (2000). Taxonomic, phylogenetic and ecological diversity of methanogenic Archaea. Anaerobe 6: 205-226.

Gentile G, Giuliano L, D’Auria G, Smedile F, Azzaro M, De Domenico $M$ et al. (2006). Study of bacterial communities in Antarctic coastal waters by a combination of $16 \mathrm{~S}$ rRNA and $16 \mathrm{~S}$ rDNA sequencing. Environ Microbiol 8: 2150-2161.

Glissman K, Chin KJ, Casper P, Conrad R. (2004). Methanogenic pathway and archaeal community structure in the sediment of eutrophic Lake Dagow: effect of temperature. Microb Ecol 48: 389-399.

Grosskopf R, Janssen PH, Liesack W. (1998a). Diversity and structure of the methanogenic community in anoxic rice paddy soil microcosms as examined by cultivation and direct $16 \mathrm{~S}$ rRNA gene sequence retrieval. Appl Environ Microbiol 64: 960-969.

Grosskopf R, Stubner S, Liesack W. (1998b). Novel euryarchaeotal lineages detected on rice roots and in the anoxic bulk soil of flooded rice microcosms. Appl Environ Microbiol 64: 4983-4989.

Guindon S, Gascuel O. (2003). A simple, fast, and accurate algorithm to estimate large phylogenies by maximum likelihood. Syst Biol 52: 696-704.

Høj L, Olsen RA, Torsvik VL. (2005). Archaeal communities in High Arctic wetlands at Spitsbergen, Norway $\left(78^{\circ} \mathrm{N}\right)$ as characterized by $16 \mathrm{~S}$ rRNA gene fingerprinting. FEMS Microbiol Ecol 53: 89-101.

Høj L, Olsen RA, Torsvik VL. (2008). Effects of temperature on the diversity and community structure of known methanogenic groups and other Archaea in high Arctic peat. ISME J 2: 37-48.

Høj L, Rusten M, Haugen LE, Olsen RA, Torsvik VL. (2006). Effects of water regime on archaeal community composition in Arctic soils. Environ Microbiol 8: 984-996.

Horn MA, Matthies C, Kusel K, Schramm A, Drake HL. (2003). Hydrogenotrophic methanogenesis by moderately acid-tolerant methanogens of a methane-emitting acidic peat. Appl Environ Microbiol 69: 74-83.

Hornibrook ERC, Longstaffe FJ, Fyfe WS. (1997). Spatial distribution of microbial methane production pathways in temperate zone wetland soils: stable carbon and hydrogen isotope evidence. Geochim Cosmochim Acta 61: 745-753.

Huber T, Faulkner G, Hugenholtz P. (2004). Bellerophon: a program to detect chimeric sequences in multiple sequence alignments. Bioinformatics 20: 2317-2319. 
Jaatinen K, Tuittila ES, Laine J, Yrjälä K, Fritze H. (2005). Methane-oxidizing bacteria in a Finnish raised mire complex: effects of site fertility and drainage. Microb Ecol 50: 429-439.

Jetten MSM, Stams AJM, Zehnder AJB. (1992). Methanogenesis from acetate: a comparison of the acetate metabolism in Methanothrix soehngenii and Methanosarcina spp. FEMS Microbiol Rev 88: 181-198.

Juottonen H, Galand PE, Tuittila ES, Laine J, Fritze H, Yrjälä K. (2005). Methanogen communities and Bacteria along an ecohydrological gradient in a northern raised bog complex. Environ Microbiol 7: 1547-1557.

Jurgens G, Lindström K, Saano A. (1997). Novel group within the kingdom Crenarchaeota from boreal forest soil. Appl Environ Microbiol 63: 803-805.

Kemnitz D, Kolb S, Conrad R. (2007). High abundance of Crenarchaeota in a temperate acidic forest soil. FEMS Microbiol Ecol 60: 442-448.

Kerkhof L, Kemp P. (1999). Small ribosomal RNA content in marine Proteobacteria during non-steady-state growth. FEMS Microbiol Ecol 30: 253-260.

Kerkhof L, Ward BB. (1993). Comparison of nucleic acid hybridization and fluorometry for measurement of the relationship between RNA/DNA ratio and growth rate in a marine bacterium. Appl Environ Microbiol 59: 1303-1309.

Kettunen A, Kaitala V, Lehtinen A, Lohila A, Alm J, Silvola J et al. (1999). Methane production and oxidation potentials in relation to water table fluctuations in two boreal mires. Soil Biol Biochem 31: 1741-1749.

Korkama-Rajala T, Müller MM, Pennanen T. (2007). Decomposition and fungi of needle litter from slowand fast-growing Norway spruce (Picea abies) clones. Microb Ecol, advance online publication 18 October 2007; doi: 10.1007/s00248-007-9326-y.

Kotsyurbenko OR. (2005). Trophic interactions in the methanogenic microbial community of low-temperature terrestrial ecosystems. FEMS Microbiol Ecol 53: $3-13$.

Kotsyurbenko OR, Chin KJ, Glagolev MV, Stubner S, Simankova MV, Nozhevnikova AN et al. (2004). Acetoclastic and hydrogenotrophic methane production and methanogenic populations in an acidic WestSiberian peat bog. Environ Microbiol 6: 1159-1173.

Lipson DA, Schadt CW, Schmidt SK. (2002). Changes in soil microbial community structure and function in an alpine dry meadow following spring snow melt. Microb Ecol 43: 307-314.

Lu Y, Lueders T, Friedrich MW, Conrad R. (2005). Detecting active methanogenic populations on rice roots using stable isotope probing. Environ Microbiol 7: 326-336.

Lueders T, Friedrich MW. (2002). Effects of amendment with ferrihydrite and gypsum on the structure and activity of methanogenic populations in rice field soil. Appl Environ Microbiol 68: 2484-2494.

Luton PE, Wayne JM, Sharp RJ, Riley PW. (2002). The mcrA gene as an alternative to $16 \mathrm{~S}$ rRNA in the phylogenetic analysis of methanogen populations in landfill. Microbiology 148: 3521-3530.

Marchesi JR, Weightman AJ, Cragg BA, Parkes RJ, Fry JC. (2001). Methanogen and bacterial diversity and distribution in deep gas hydrate sediments from the Cascadia Margin as revealed by $16 \mathrm{~S}$ rRNA molecular analysis. FEMS Microbiol Ecol 34: 221-228.
Melloh RA, Crill PM. (1996). Winter methane dynamics in a temperate peatland. Global Biogeochem Cycles 10: 247-254.

Mengoni A, Tatti E, Decorosi F, Viti C, Bazzicalupo M, Giovannetti L. (2005). Comparison of $16 \mathrm{~S}$ rRNA and 16S rDNA T-RFLP approaches to study bacterial communities in soil microcosms treated with chromate as perturbing agent. Microb Ecol 50: 375-384.

Metje M, Frenzel P. (2005). Effect of temperature on anaerobic ethanol oxidation and methanogenesis in acidic peat from a northern wetland. Appl Environ Microbiol 71: 8191-8200.

Metje M, Frenzel P. (2007). Methanogenesis and methanogenic pathways in a peat from subarctic permafrost. Environ Microbiol 9: 954-964.

Nicol GW, Campbell CD, Chapman SJ, Prosser JI. (2007). Afforestation of moorland leads to changes in crenarchaeal community structure. FEMS Microbiol Ecol 60: $51-59$

Panikov NS, Dedysh SN. (2000). Cold season $\mathrm{CH}_{4}$ and $\mathrm{CO}_{2}$ emission from boreal peat bogs (West Siberia): winter fluxes and thaw activation dynamics. Global Biogeochem Cycles 14: 1071-1080.

Rinne J, Riutta T, Pihlatie M, Aurela M, Haapanala S, Tuovinen JP et al. (2007). Annual cycle of methane emission from a boreal fen measured by the eddy covariance technique. Tellus B 59: 449-457.

Riutta T, Laine J, Aurela M, Rinne J, Vesala T, Laurila T et al. (2007). Spatial variation in plant community functions regulates carbon gas dynamics in a boreal fen ecosystem. Tellus $B$ 59: 838-852.

Röling WFM. (2007). Do microbial numbers count? Quantifying the regulation of biogeochemical fluxes by population size and cellular activity. FEMS Microbiol Ecol 62: 202-210.

Rooney-Varga JN, Giewat MW, Duddleston KN, Chanton JP, Hines ME. (2007). Links between archaeal community structure, vegetation type and methanogenic pathway in Alaskan peatlands. FEMS Microbiol Ecol 60: $240-251$.

Saarnio S, Alm J, Silvola J, Lohila A, Nykänen H, Martikainen PJ. (1997). Seasonal variation in $\mathrm{CH}_{4}$ emissions and production and oxidation potentials at microsites on an oligotrophic pine fen. Oecologia 110: 414-422.

Sakai S, Imachi H, Sekiguchi Y, Ohashi A, Harada H, Kamagata Y. (2007). Isolation of key methanogens for global methane emission from rice paddy fields: a novel isolate affiliated with the clone cluster rice cluster I. Appl Environ Microbiol 73: 4326-4331.

Schulz S, Matsuyama H, Conrad R. (1997). Temperature dependence of methane production from different precursors in a profundal sediment (Lake Constance). FEMS Microbiol Ecol 22: 207-213.

Simankova MV, Kotsyurbenko OR, Lueders T, Nozhevnikova AN, Wagner B, Conrad R et al. (2003). Isolation and characterization of new strains of methanogens from cold terrestrial habitats. Syst Appl Microbiol 26: 312-318

Simon HM, Dodsworth JA, Goodman RM. (2000). Crenarchaeota colonize terrestrial plant roots. Environ Microbiol 2: 495-505.

Svensson BH, Sundh I. (1992). Factors affecting methane production in peat soils. Suo 43: 183-190.

ter Braak CJF, Prentice IC. (1988). A theory of gradient analysis. Adv Ecol Res 18: 271-317. 
ter Braak CJF, Šmilauer P. (2002). CANOCO Reference Manual and CanoDraw for Windows user's Guide: Software for Canonical Community Ordination (version 4.5). Microcomputer Power: Ithaca, NY, USA.

Turunen J, Tomppo E, Tolonen K, Reinikainen A. (2002). Estimating carbon accumulation rates of undrained mires in Finland-application to boreal and subarctic regions. Holocene 12: 69-80.

Utsumi M, Belova SE, King GM, Uchiyama H. (2003). Phylogenetic comparison of methanogen diversity in different wetland soils. J Gen Appl Microbiol 49: 75-83.

Valentine DW, Holland EA, Schimel DS. (1994). Ecosystem and physiological controls over methane production in northern wetlands. J Geophys Res 99: 1563-1571.

Wagner D, Gattinger A, Embacher A, Pfeiffer E, Schloter M, Lipski A. (2007). Methanogenic activity and biomass in Holocene permafrost deposits of the Lena Delta, Siberian Arctic and its implication for the global methane budget. Global Change Biol 13: 1089-1099.

Whalen SC. (2005). Biogeochemistry of methane exchange between natural wetlands and the atmosphere. Environ Eng Sci 22: 73-94.

Yavitt JB, Lang GE, Wieder RK. (1987). Control of carbon mineralization to $\mathrm{CH}_{4}$ and $\mathrm{CO}_{2}$ in anaerobic, Sphagnum-derived peat from Big Run Bog, West Virginia. Biogeochemistry 4: 141-157. 